\title{
Effect of Pasteurization and Ripening Temperature on Chemical and Sensory Characteristics of Traditional Motal Cheese
}

\author{
Ashkan Rezaei ${ }^{1,2}{ }^{2}$ Kazem Alirezalu ${ }^{3, *}{ }^{\infty}$, Sodeif Azadmard Damirchi ${ }^{1}$, Javad Hesari ${ }^{1}$, \\ Photis Papademas ${ }^{4}\left(\mathbb{D}\right.$, Rubén Domínguez ${ }^{5}{ }^{\circ}$, José M. Lorenzo ${ }^{5,6, *(1)}$ and Milad Yaghoubi ${ }^{1}$ \\ 1 Department of Food Science and Technology, Faculty of Agriculture, University of Tabriz, Tabriz 51666, Iran; \\ ashkanrezaei52@gmail.com (A.R.); s-azadmard@tabrizu.ac.ir (S.A.D.); jhesari@tabrizu.ac.ir (J.H.); \\ m.yaghoubi97@ms.tabrizu.ac.ir (M.Y.) \\ 2 ETKA Co., Tehran 009821, Iran \\ 3 Department of Food Science and Technology, Ahar Faculty of Agriculture and Natural Resources, \\ University of Tabriz, Tabriz 51666, Iran \\ 4 Department of Agricultural Sciences, Biotechnology and Food Science, Cyprus University of Technology, \\ Limassol 50329, Cyprus; photis.papademas@cut.ac.cy \\ 5 Centro Tecnológico de la Carne de Galicia, Parque Tecnológico de Galicia, rúa Galicia n 4 , \\ San Cibrao das Viñas, 32900 Ourense, Spain; rubendominguez@ceteca.net \\ 6 Área de Tecnología de los Alimentos, Facultad de Ciencias de Ourense, Universidad de Vigo, \\ 32004 Ourense, Spain \\ * Correspondence: kazem.alirezalu@tabrizu.ac.ir (K.A.); jmlorenzo@ceteca.net (J.M.L.)
}

Received: 10 August 2020; Accepted: 25 September 2020; Published: 28 September 2020

\begin{abstract}
The appropriate physicochemical and sensory characteristics and the traditional elaboration process of Motal cheese resulted in a high consumer acceptability. However, different process steps could have a significant effect on these characteristics. Thus, the present study aimed to investigate the effects of pasteurization, ripening time, and ripening temperature $\left(6^{\circ} \mathrm{C}\right.$ and $\left.12{ }^{\circ} \mathrm{C}\right)$ on the physicochemical properties, sensory characteristics, and proteolysis and lipolysis phenomenon of traditional Motal cheese. The cheeses were evaluated each 15 days during 3 months of ripening process. The results showed that pasteurization and ripening temperature had a significant effect on $\mathrm{pH}$, acidity, dry matter, fat, protein, and salt $(p<0.05)$, which were higher in pasteurized cheeses ripened at higher temperature $\left(12^{\circ} \mathrm{C}\right)$. Moreover, the content of these parameters increased as ripening progressed. Proteolysis and lipolysis intensity were higher in the cheeses elaborated form raw milk and ripened at $12{ }^{\circ} \mathrm{C}$ (R12), mainly due to the higher activity of enzymes and/or bacteria. As a general conclusion, the pasteurization and low-temperature ripening process allows us to have a homogeneous product and ensure the microbiological stability of the cheeses, as well as presents higher physicochemical qualities than those obtained from raw milk.
\end{abstract}

Keywords: Motal cheese; physicochemical parameters; sensory properties; thermal treatment; ripening process

\section{Introduction}

Motal cheese is a kind of Tulum cheese, which is also known as "Dari Paniri". Civil and White cheese are two kinds of cheeses that are utilized in Motal cheese production. Sheep milk and cow's milk are generally used for White and Civil cheese production, respectively. Motal cheese is characterized by a creamy color, acidic flavor, and semi-hard texture, with a desirable taste crossing between Lighvan cheese (a traditional Iranian brined curd cheese from sheep's milk) and Tuluq yoghurt (a traditional 
Iranian yoghurt from sheep and cow milks) [1]. Motal cheese is extensively present in the Northwestern area of Iran and prepared like most traditional cheeses, for instance, without adding any starter and generally from the raw milk and ripened in sheepskin bag according to long-standing experience of local farmers. Thus, the indigenous species in the milk flora, endogenous surface bacteria, and enzymes and yeasts activities are the most important factors in developing the special flavor of this type of cheese [2]. On the other hand, sheepskin is considered and used by traditional producers because of ease of preparation and availability, affordability, and good permeability properties, thereby maintaining and improving the organoleptic, physical, and chemical characteristics of cheese and yoghurt [3].

Traditional cheese, which is made from raw milk, potentially has high healthy risks for consumers [4,5]. Therefore, milk pasteurization could be used as an efficient technique in cheese manufacturing to eliminate pathogenic or contaminant microorganisms [6]. Heat has the different physicochemical effects on the milk and changes its coagulation, proteolysis, and organoleptic properties in cheese-making [7]. Studying these effects with the currency of thermal process has drawn the attention of many researchers in recent years. The effect of heating milk on increasing the yield of cheese produced is one of the significant benefits of this process that is related to retaining the serum proteins coagulated and more moisture in the final product [8,9]. However, pasteurization not only causes the destruction of heat-sensitive microorganisms [8] and decreases the number of Propionibacterium bacteria and heterofermentative lactobacilli; it also changes the catabolism of many organic acids, such as lactate and citrate, activates or deactivates the proenzymes and natural enzymes of milk, and changes the activity of lactic acid bacteria [10]. Natural lactic bacteria in milk have better activity than starter added because they are better adapted to the conditions, and this makes the difference between the cheeses produced from raw and pasteurized milk. The natural enzymes of milk, such as alkaline proteases (plasmin) and acidic proteases and lipase, are some factors affecting the flavor development in cheese that are destroyed by pasteurization [11]. The effect of temperature is also non-specific. It means that it increases the rate of adverse reactions and the possibility of growing the unwanted and contaminating microorganisms, such as mold, as much as it increases the rate of proteolysis. In this regard, Prato cheese produced with a lactic acid bacteria culture attenuated the development of renal calculi (formation of stones in the urinary system) [12].

Thus, the aim of this study was to assess the effect of pasteurization process and storage temperature $\left(6\right.$ and $\left.12{ }^{\circ} \mathrm{C}\right)$ on the physicochemical properties, lipolysis and proteolysis, and sensorial characteristics during the ripening process.

\section{Materials and Methods}

\subsection{Motal Cheesemaking}

Pasteurized and raw sheep milk were purchased in a local dairy industry (Moghna, Ardebil). Commercial fungal rennet was obtained from Meito Sangyo (Rhizomucor pusillus + Rhizomucor miehei rennet, Tokyo, Japan). Cheese samples were manufactured at the Food Science and Technology laboratory of Agriculture Faculty of Tabriz University (Tabriz, Iran). In this study, cheese was produced from both pasteurized and raw milk. For producing the raw cheese, rennet $(0.01 \mathrm{~g} / \mathrm{L} \mathrm{of} \mathrm{milk)} \mathrm{wad}$ added and stirred at the temperature of $35^{\circ} \mathrm{C}$ and, finally, added to the milk. The milk was coagulated for $45 \mathrm{~min}$. After coagulation, the curd was cut into 8-10 $\mathrm{mm}$ cubes with a knife and then transferred to a clean cotton cloth and pressed for $90 \mathrm{~min}$. After $1.5 \mathrm{~h}$, the cheese samples produced were crushed into smaller pieces by hand and mixed with salt $(30 \mathrm{~g} / \mathrm{kg})$. After salting, the pieces of cheese were filled in the initial skin prepared (Tejan), and then the filled skin was put under pressure for $48 \mathrm{~h}$ at $20{ }^{\circ} \mathrm{C}$ for dehydration. After this, it was transferred to the final skin prepared, filled, and closed.

For cheese produced from pasteurized milk, the milk was initially heated at $65{ }^{\circ} \mathrm{C}$ for $30 \mathrm{~min}$. After the pasteurization, the milk was cooled at $39^{\circ} \mathrm{C}$, and then the starter $1 \%$ (Lactococcus: lactobacillus with ratio 1:1) was added. After $10 \mathrm{~min}$, the rennet with the amount of $0.01 \mathrm{~g} / \mathrm{L}$ of milk was added. Then, the rest of the steps were the same as raw cheese production. Finally, the ripening occurred for 
3 months in both cheeses, ripened at $6{ }^{\circ} \mathrm{C}$ and $12{ }^{\circ} \mathrm{C}$. Raw (R6 and R12) and pasteurized (P6 and P12) cheese samples were randomly ripened at 6 and $12^{\circ} \mathrm{C}$. Cheese samples were analyzed after $1,15,30$, $45,60,75$, and 90 days of ripening for physico-chemical analysis, lipolysis, and proteolysis. In addition, the sensorial analysis of cheese was conducted after 90 days of process.

\subsection{Chemical and Physicochemical Analysis}

Dry matter (by the oven drying method at $105 \pm 2{ }^{\circ} \mathrm{C}$ ), total nitrogen (by the Kjeldahl method and conversion factor $=6.38$ ), fat (by the Gerber method), and salt (by the potentiometric method) contents of Motal cheese were determined according with reported method by Marshall [13]. The $\mathrm{pH}$ value was determined using a pH-meter (model Kent Hanna, Herisau, Switzerland) by mixing cheese and distilled water (1:10). Titratable acidity (g lactic acid/ $100 \mathrm{~g}$ cheese) was determined with titrimetric methods [13]. All experiments were conducted in triplicate.

The lipolysis degree of Motal samples was measured using total lipid extraction by diethyl ether, and the acidity index of the lipid was measured from ethanolic titration as described by Núñez et al. [14]. For soluble nitrogen (SN) determination, $30 \mathrm{~g}$ of cheese was homogenized with distilled water $(60 \mathrm{~mL})$ for $5 \mathrm{~min}, \mathrm{pH}$ was adjusted at 4.6 , and left at $25^{\circ} \mathrm{C}$ for $30 \mathrm{~min}$. Then, $\mathrm{pH}$ was again adjusted at 4.6 and held at $40^{\circ} \mathrm{C}$ for $30 \mathrm{~min}$, centrifuged $(4000 \times \mathrm{g}, 30 \mathrm{~min})$, and filtered through Whatman filter paper No. 42 and glass wool. The supernatant and sediment were determined for $\mathrm{SN}$ and electrophoresis, respectively [15]. The content of SN fractions reported as a percentage of total nitrogen (\%SN/TN).

Non-protein nitrogen (NPN) determination, $5 \mathrm{~mL}$ of $60 \%$ TCA (trichloroacetic acid) solution was mixed to $20 \mathrm{~mL}$ of SN supernatant and held at $25^{\circ} \mathrm{C}$ for $30 \mathrm{~min}$, centrifuged at $5000 \times \mathrm{g}$ for $10 \mathrm{~min}$, and the mixture was filtered through Whatman No. 42 filter paper [15]. The content of NPN fractions reported as a percentage of total nitrogen (\%NPN/TN). Urea polyacrylamide gel electrophoresis (urea-PAGE) was used for degradation of casein fractions according with method described by Andrews [16]. Casein samples were prepared after freeze-drying as reported by Kaminaridesa and Koukiassa [17] and staining by Coomassie Brilliant Blue G-250, and destaining by pure water was carried out by the method of Shalabi and Fox [18].

\subsection{Sensory Evaluation}

The sensory tests were carried out according to ethics approval code: 1058801/2012 in Iranian Research Institute for Information Science and Technology. Studying the sensory characteristics of cheese samples (50 $\mathrm{g}$ chopped cheese for each member), including the characteristics of appearance (cheese color), texture (mouth-feel), flavor characteristics (animal and foreign flavor, moldiness and mustiness flavor (stale or moldy in taste), salty flavor, bitter flavor, total cheese flavor), and odors (sheep odor, salty odor, and total cheese odor) was conducted by fifteen trained panelists (eight females, seven males; age 20-25 yr), randomly on the 90th day of ripening and 9-point hedonic (' 9 ' corresponded to 'excellent', and ' 1 ' corresponded to 'unacceptable') [19]. All tests were carried out in duplicate, individually, and equipped with daylight. About $100 \mathrm{~g}$ cheese was presented to each member.

\subsection{Statistical Analysis}

Statistical analysis used in this study was conducted by a factorial experiment based on a completely randomized block design with the factors of pasteurization (pasteurized milk, raw milk) and the ripening temperature $\left(6\right.$ and $12{ }^{\circ} \mathrm{C}$ ) with three replications. The data analysis was conducted by using Duncan's multiple-range test at the probability level of $5 \%$ and by using SAS software version 1.9. Excel software was used to draw the graph.

\section{Results and Discussion}

In the present study, the use of a starter culture in pasteurized Motal cheeses was based on the results published in a recent research [20]. The most common lactic acid bacteria isolated from raw milk 
in Ardebil region were Lactobacillus and Lactococcus, so, in the present research, their freeze-dried cultures were used to simulate the primary bacteria.

\subsection{Dry Matter Changes during Ripening}

Results of statistical analysis showed that pasteurization process, ripening temperature, and ripening time have a significant effect $(p<0.05)$ on dry matter changes during the ripening process (Table 1). The results of this study displayed that cheese samples manufactured with pasteurized milk had higher dry matter content in comparison with cheese prepared with raw milk. These results agree with those reported by Sert et al. [21], who indicated that, at the end of ripening process, the dry mater of Tulum cheese was $31.35 \%$ and $33.51 \%$ for cheese made with raw and heated milk, respectively. In addition, other authors found the same behavior in dry matter content of Tulum, Batzos, and pasta-filata cheeses at the end of ripening process [22-24]. Proteolysis leads to softening in cheese texture. The increase of temperature increases the hardness of cheese due to a decrease in moisture content that it can overcome the softening effect of proteolysis. According to Gaya et al. [25], increasing the temperature and the ripening time increase the amount of texture firmness that can be due to the dominance of hardening effect of moisture loss compared to the softening effect of proteolysis.

Our results showed the P12 presenting higher dry matter than the other ones. This finding agrees with data reported by Gaya et al. [25], who stated that the ripening at $12{ }^{\circ} \mathrm{C}$ increased the dry matter content more than the ripening at 4 or $8{ }^{\circ} \mathrm{C}$, and it could be due to more intensive moisture removal. However, at $4{ }^{\circ} \mathrm{C}$, the dry matter content generally decreased over time, and it could be due to the dehydration of cheese proteins at low temperature. The most important effect of heat treatment is related to the formation of heat complexes between the proteins of whey and casein. Thus, the pasteurization process changes the nature of $\beta$ - lactoglobulin and formation of a complex between the molecules of $\beta$-lactoglobulin, $\alpha$-lactalbumin, and k-casein by disulfide bonds, which it is consistent with the results reported by Fox et al. [26]. 
Table 1. Physicochemical properties of Motal cheese during the 90-day ripening process.

\begin{tabular}{|c|c|c|c|c|c|c|c|c|}
\hline & & \multicolumn{7}{|c|}{ Ripening Time (Day) } \\
\hline & & 1 & 15 & 30 & 45 & 60 & 75 & 90 \\
\hline \multirow{4}{*}{$\mathrm{pH}$} & P6 & $5.64 \pm 0.008^{\mathrm{Bd}}$ & $5.01 \pm 0.008 \mathrm{Ac}$ & $4.98 \pm 0.005^{\mathrm{Aa}}$ & $4.91 \pm 0.007 \mathrm{Ca}$ & $4.75 \pm 0.003 \mathrm{Cbc}$ & $4.82 \pm 0.002^{\mathrm{Bab}}$ & $4.87 \pm 0.009 \mathrm{Ba}$ \\
\hline & $\mathrm{P} 12$ & $5.64 \pm 0.008^{\mathrm{Bd}}$ & $5.16 \pm 0.005^{\mathrm{Bc}}$ & $4.92 \pm 0.002 \mathrm{Ab}$ & $4.85 \pm 0.008^{\mathrm{BCb}}$ & $4.61 \pm 0.011 \mathrm{Ba}$ & $4.75 \pm 0.001 \mathrm{Ba}$ & $4.84 \pm 0.009 \mathrm{Bab}$ \\
\hline & R6 & $5.32 \pm 0.006 \mathrm{Ae}$ & $5.01 \pm 0.004 \mathrm{Ad}$ & $4.91 \pm 0.002 \mathrm{Acd}$ & $4.84 \pm 0.001 \mathrm{BCbc}$ & $4.59 \pm 0.002 \mathrm{Ba}$ & $4.79 \pm 0.005^{\mathrm{Bb}}$ & $4.82 \pm 0.002 \mathrm{ABbc}$ \\
\hline & $\mathrm{R} 12$ & $5.32 \pm 0.006^{\mathrm{Ad}}$ & $4.95 \pm 0.002 \mathrm{Ac}$ & $4.85 \pm 0.009 \mathrm{Abc}$ & $4.70 \pm 0.002 \mathrm{Ab}$ & $4.51 \pm 0.001 \mathrm{Aa}$ & $4.61 \pm 0.002 \mathrm{Aab}$ & $4.71 \pm 0.002 \mathrm{Ab}$ \\
\hline \multirow{4}{*}{ Acidity $(\%)$} & P6 & $0.45 \pm 0.012 \mathrm{Aa}$ & $0.68 \pm 0.002 \mathrm{Aa}$ & $0.86 \pm 0.005^{\mathrm{Ab}}$ & $1.17 \pm 0.006^{\mathrm{Ac}}$ & $1.21 \pm 0.003 \mathrm{Ac}$ & $1.24 \pm 0.008 \mathrm{Ac}$ & $1.20 \pm 0.008 \mathrm{Ac}$ \\
\hline & $\mathrm{P} 12$ & $0.45 \pm 0.012 \mathrm{Aa}$ & $0.81 \pm 0.005 \mathrm{Bb}$ & $1.09 \pm 0.023 \mathrm{ABc}$ & $1.28 \pm 0.075 \mathrm{ABd}$ & $1.48 \pm 0.081 \mathrm{ABe}$ & $1.39 \pm 0.044 \mathrm{ABe}$ & $1.31 \pm 0.049 \mathrm{ABe}$ \\
\hline & R6 & $0.84 \pm 0.006^{\text {Ва }}$ & $1.07 \pm 0.11$ BCab & $1.13 \pm 0.012 \mathrm{Bb}$ & $1.34 \pm 0.031 \mathrm{BCc}$ & $1.50 \pm 0.005 \mathrm{Bc}$ & $1.37 \pm 0.006 \mathrm{ABc}$ & $1.39 \pm 0.012 \mathrm{ABc}$ \\
\hline & R12 & $0.84 \pm 0.006^{\mathrm{Ba}}$ & $1.11 \pm 0.006 \mathrm{Cb}$ & $1.24 \pm 0.017^{\mathrm{Bc}}$ & $1.49 \pm 0.006^{\mathrm{Ccd}}$ & $1.61 \pm 0.016^{\mathrm{Bd}}$ & $1.48 \pm 0.007 \mathrm{Bd}$ & $1.40 \pm 0.007 \mathrm{Bcd}$ \\
\hline \multirow{4}{*}{ Dry matter (\%) } & P6 & $35.52 \pm 0.061 \mathrm{Aa}$ & $40.80 \pm 0.296^{\mathrm{ABb}}$ & $45.81 \pm 0.284^{\mathrm{Cc}}$ & $48.65 \pm 0.288^{\mathrm{Cd}}$ & $49.41 \pm 0.070^{\mathrm{Bd}}$ & $49.92 \pm 0.101 \mathrm{Bd}$ & $52.23 \pm 0.256 \mathrm{Ce}$ \\
\hline & $\mathrm{P} 12$ & $35.52 \pm 0.061 \mathrm{Aa}$ & $42.81 \pm 0.231 \mathrm{Bb}$ & $48.33 \pm 0.230 \mathrm{Dc}$ & $49.89 \pm 0.019$ Ccd & $50.04 \pm 0.058^{\mathrm{Bcd}}$ & $50.41 \pm 0.158^{\mathrm{Bcd}}$ & $53.22 \pm 0.065^{\mathrm{Cd}}$ \\
\hline & R6 & $34.61 \pm 0.032 \mathrm{Aa}$ & $38.14 \pm 0.142 \mathrm{Ab}$ & $42.18 \pm 0.109$ Ac & $43.60 \pm 0.028 \mathrm{Ac}$ & $43.88 \pm 0.338 \mathrm{Ac}$ & $45.78 \pm 0.164 \mathrm{Acd}$ & $47.11 \pm 0.333 \mathrm{Ad}$ \\
\hline & R12 & $34.61 \pm 0.032 \mathrm{Aa}$ & $40.14 \pm 0.335 \mathrm{ABb}$ & $44.82 \pm 0.218^{\mathrm{BCc}}$ & $45.31 \pm 0.042 \mathrm{Ac}$ & $48.12 \pm 0.484^{\mathrm{Bd}}$ & $48.86 \pm 0.392 \mathrm{Bd}$ & $49.58 \pm 0.72 \mathrm{Bd}$ \\
\hline \multirow{4}{*}{ Fat $(\%)$} & P6 & $16.83 \pm 0.166^{\mathrm{Aa}}$ & $16.60 \pm 0.166^{\mathrm{Aa}}$ & $18.16 \pm 0.044 \mathrm{CDbc}$ & $19.66 \pm 0.086^{\mathrm{Bc}}$ & $19.66 \pm 0.132^{\mathrm{Bc}}$ & $19.66 \pm 0.323 \mathrm{Bc}$ & $19.51 \pm 0.288^{\mathrm{Bc}}$ \\
\hline & $\mathrm{P} 12$ & $16.83 \pm 0.166 \mathrm{Aa}$ & $16.50 \pm 0.122 \mathrm{Aa}$ & $19.33 \pm 0.166^{\mathrm{Db}}$ & $19.82 \pm 0.106^{\mathrm{Bb}}$ & $20.16 \pm 0.196^{\mathrm{Bb}}$ & $20.32 \pm 0.156^{\mathrm{Bb}}$ & $20.36 \pm 0.162^{B b}$ \\
\hline & R6 & $15.33 \pm 0.165^{\mathrm{Ab}}$ & $14.00 \pm 0.067 \mathrm{Aa}$ & $15.66 \pm 0.071 \mathrm{Ac}$ & $15.83 \pm 0.132 \mathrm{Ac}$ & $15.83 \pm 0.129 \mathrm{Ac}$ & $16.00 \pm 0.285 \mathrm{Ac}$ & $16.16 \pm 0.032 \mathrm{Ac}$ \\
\hline & $\mathrm{R} 12$ & $15.23 \pm 0.165 \mathrm{Aa}$ & $14.66 \pm 0.166$ Аа & $17.50 \pm 0.088^{\mathrm{BCb}}$ & $19.0 \pm 0.044^{\mathrm{Bb}}$ & $19.33 \pm 0.118^{\mathrm{Bbc}}$ & $19.83 \pm 0.132 \mathrm{Bc}$ & $19.66 \pm 0.098^{B c}$ \\
\hline \multirow{4}{*}{ Protein $(\%)$} & P6 & $15.28 \pm 0.032 \mathrm{Ba}$ & $16.56 \pm 0.049^{\mathrm{Bb}}$ & $17.90 \pm 0.067 \mathrm{ABb}$ & $19.84 \pm 0.046^{\mathrm{Bbc}}$ & $19.85 \pm 0.165 \mathrm{ABbc}$ & $20.24 \pm 0.135 \mathrm{ABbc}$ & $20.45 \pm 0.125^{\mathrm{Ac}}$ \\
\hline & $\mathrm{P} 12$ & $15.28 \pm 0.032 \mathrm{Ba}$ & $16.99 \pm 0.091^{\mathrm{Bb}}$ & $18.52 \pm 0.101 \mathrm{Bc}$ & $19.73 \pm 0.249 \mathrm{Bcd}$ & $20.46 \pm 0.128$ Bde & $21.08 \pm 0.173 \mathrm{Be}$ & $21.46 \pm 0.282 \mathrm{Ae}$ \\
\hline & R6 & $14.37 \pm 0.093 \mathrm{Aa}$ & $15.36 \pm 0.089 \mathrm{Ab}$ & $16.63 \pm 0.106 \mathrm{Ac}$ & $17.75 \pm 0.112 \mathrm{Acd}$ & $18.86 \pm 0.092 \mathrm{Ad}$ & $18.96 \pm 0.062 \mathrm{Ad}$ & $19.24 \pm 0.146 \mathrm{Ad}$ \\
\hline & R12 & $14.37 \pm 0.093 \mathrm{Aa}$ & $15.91 \pm 0.132 \mathrm{ABb}$ & $17.41 \pm 0.066 \mathrm{ABc}$ & $18.71 \pm 0.214 \mathrm{ABc}$ & $19.45 \pm 0.096 \mathrm{ABcd}$ & $19.73 \pm 0.119 \mathrm{ABd}$ & $19.92 \pm 0.254 \mathrm{Ad}$ \\
\hline
\end{tabular}

P6: cheese produced from pasteurized milk and ripened at $6{ }^{\circ} \mathrm{C} ;$ P12: cheese produced from pasteurized milk and ripened at $12{ }^{\circ} \mathrm{C}$; R6: cheese produced from raw milk and ripened at $6{ }^{\circ} \mathrm{C} ;$ R12 cheese produced from raw milk and ripened at $12{ }^{\circ} \mathrm{C}$. A-D Mean values in each column and from each parameter with different number differ significantly $(p<0.05)$. a-e Mean values

in each row with different letters differ significantly $(p<0.05)$. 


\section{2. $p H$ Changes during Ripening}

Regarding $\mathrm{pH}$, statistical analysis showed that the pasteurization process, ripening temperature, and ripening time significantly influenced $\mathrm{pH}$ values $(p<0.05)$ (Table 1$)$. Between the cheeses ripened at the same temperature, $\mathrm{pH}$ in cheeses produced from raw milk was lower than in cheeses produced from pasteurized milk. The results of this study are in agreement with data reported by Sert et al. [21], who evaluated $\mathrm{pH}$ changes during ripening in Tulum cheese. These authors showed $\mathrm{pH}$ values of 5.52 and 5.64 in Tulum cheeses prepared with raw and pasteurized milk, respectively. In this regard, the presence of natural enzymes in milk, especially lipase enzyme, which leads to fatty acids production (by lipolysis), may be the main reason for low $\mathrm{pH}$ values in cheese produced by raw milk [22]. Furthermore, production of lactic acid by lactose fermentation (by lactic acid bacteria) may be another reason for $\mathrm{pH}$ values changes in this type of cheeses [22,27]. On the other hand, the $\mathrm{pH}$ was higher at lower temperatures of ripening (P6 and R6) than at high temperatures (P12 and R12); thus, it seems that, at low temperatures, the factors affecting the increase of $\mathrm{pH}$ are able to prevent a high decrease in $\mathrm{pH}$, which is consistent with the results reported by Folkertsma et al. [28] and Kujawski et al. [29].

After the 8th week, the $\mathrm{pH}$ began to increase, very likely due to the dry matter in cheese. Thus, the salt content of cheeses gradually increases so that the salt has an inhibitory effect on the activity of lactic acid bacteria and, finally, the acid production and decrease of the $\mathrm{pH}$. In addition, in the late ripening, $\mathrm{pH}$ in the cheese may increase due to lactic acid taken by molds and yeasts, as well as proteolysis process that occurs during ripening and the production of high levels of amino acids, ammonia, etc. [30,31].

\subsection{Acidity Changes during Ripening}

Results of variance analysis of cheese samples showed that the type of treatment (pasteurization process and ripening temperature) and ripening time have a significant effect $(p<0.05)$ on acidity values (Table 1). Results of experiments showed that the highest amount of acidity was related to the cheeses produced from raw milk at the temperature of $12{ }^{\circ} \mathrm{C}(\mathrm{R} 12)$. The results of this work are parallel with Sert et al. [21] in Tulum cheese, who observed that titratable acidity in cheese which was made from raw milk ranged between 1.08 and 1.38, whereas this range was between 0.7 and 1.08 in cheese samples which were made from pasteurized milk. Natural lipases which were inactivated in pasteurized milk may be the main reason for higher acidity in these samples. Furthermore, higher storage temperature leads to increases in the activity of lactic acid bacteria and produces more acid. Abdalla and Ibrahim [32] demonstrated that higher temperatures during storage could increase fermentations and acid production, which may be caused by increases in microbial flora activity. At the end of the ripening period, the amount of acidity was decreasing, which can be due to the high protein content and high buffering capacity, as well as high salt content, thus preventing further activity of lactic acid bacteria, lowering acid production, and increasing $\mathrm{pH}$ due to the production of alkaline compounds (amino acids and ammonia) [30,31].

\subsection{Fat Changes during Ripening}

The fat content was also influenced by the ripening time, ripening temperature, and pasteurization process (Table 1). The results showed that the fat content of Motal cheese prepared with pasteurized and raw milk from day 1 to day 15 had a slight decrease and from day 15 to day 90 increased, so that the fat content of P12 in day 90 presented the highest values, while the R6 had the lowest fat content, compared to other treatments. The results of this study are in agreement with Sert et al. [21], who observed that fat amount in cheese which was made from raw milk ranged from 20.9 and $29.0 \%$ during ripening, whereas this content ranged from 22.4 and $30.3 \%$ for cheese which was made from pasteurized milk. Higher moisture decrease in cheese which was made from pasteurized milk lead to higher dry matter content in this cheeses and higher fat content compared to cheese which was made from raw milk [33]. 
Furthermore, Marino and Schadt [24] reported the same results in pasta-filata cheese which was made from raw and pasteurized milk. The decrease in the fat content from day 1 to day 15 could be due to the removal of water-soluble short-chain fats to the salt-water solution, which agrees with those reported by the research conducted by Goncu and Alpkent [34] and Bakirci et al. [35].

The fat content of cheeses produced from pasteurized milkwas higher than the cheeses produced from raw milk. This fact could be explained by that fact that the pasteurization process favors fat recovery due to serum protein binding coagulated with fat cells [36]. In addition, in the cheeses made from raw milk retained natural lipases, while this enzyme is inactivated during the pasteurization process [37]. Furthermore, cheeses ripened at higher temperatures $\left(12^{\circ} \mathrm{C}\right)$ had more fat content than the cheeses ripened at $6^{\circ} \mathrm{C}$, which could possibly be due to the effect of higher temperature on increasing the dry matter and, thus, the fat content.

\subsection{Salt Changes during Ripening}

As occurs in the proximate parameters, salt content was significantly $(p<0.05)$ influenced by the pasteurization, ripening time, and ripening temperature. The salt fluctuation of this study is shown in Table 2.

During ripening process, the salt content in both cheeses produced from pasteurized milk ( 6 and $\left.12{ }^{\circ} \mathrm{C}\right)$ and cheeses produced from raw milk $\left(6\right.$ and $\left.12{ }^{\circ} \mathrm{C}\right)$ suffered a significant increase $(p<0.05)$. Other researchers $[27,38]$ reported similar results in salt fluctuation during ripening in Urfa, Domiati, and Urfa cheeses. This fact could be related to the dry matter increase throughout the ripening process, which resulted in higher amount of salt than in the first ripening days (cheeses with higher moisture amount). Furthermore, this increase was higher in P6 and P12 than R6 and R12. The results of this work are in agreement with Sert et al. [21] in Tulum cheese. These authors indicated that salt content in cheeses produced from raw milk on the first day of ripening had a $7.0 \%$ ratio of salt in dry matter, which was increased to $9.8 \%$ at the end of ripening, whereas this amount for cheeses produced from pasteurized milk was $7.8 \%$ and $12 \%$. As reported in yjr dry matter section, the pasteurization resulted in a higher dry matter; thus, the increase in salt content is due to the variations in dry matter between cheeses elaborated with raw and pasteurized milk. 
Table 2. Physicochemical properties of Motal cheese during the 90-day ripening process.

\begin{tabular}{|c|c|c|c|c|c|c|c|c|}
\hline & & \multicolumn{7}{|c|}{ Ripening Time (Day) } \\
\hline & & 1 & 15 & 30 & 45 & 60 & 75 & 90 \\
\hline \multirow{4}{*}{ Salt (\%) } & P6 & $3.66 \pm 0.121 \mathrm{Aa}$ & $6.21 \pm 0.0^{\mathrm{Cb}}$ & $7.01 \pm 0.044^{\mathrm{Bc}}$ & $8.58 \pm 0.042 \mathrm{Cd}$ & $9.04 \pm 0.027 \mathrm{Bd}$ & $9.32 \pm 0.024 \mathrm{Cd}$ & $9.71 \pm 0.045^{\mathrm{Cd}}$ \\
\hline & $\mathrm{P} 12$ & $3.66 \pm 0.121 \mathrm{Aa}$ & $5.83 \pm 0.017 \mathrm{Cac}$ & $6.51 \pm 0.013^{\mathrm{Bc}}$ & $7.61 \pm 0.05^{\mathrm{BC}}$ & $8.73 \pm 0.025^{\mathrm{Bc}}$ & $9.06 \pm 0.031 \mathrm{Ccd}$ & $9.50 \pm 0.018^{\mathrm{Ccd}}$ \\
\hline & R6 & $1.84 \pm 0.008^{\mathrm{Ba}}$ & $2.67 \pm 0.032 \mathrm{Ab}$ & $3.63 \pm 0.014^{\mathrm{Ac}}$ & $4.25 \pm 0.034 \mathrm{Ad}$ & $4.73 \pm 0.023 \mathrm{Ad}$ & $5.55 \pm 0.043^{\mathrm{Bcd}}$ & $6.14 \pm 0.043^{\mathrm{Bcd}}$ \\
\hline & R12 & $1.84 \pm 0.008^{\mathrm{Ba}}$ & $4.06 \pm 0.002^{\mathrm{Bb}}$ & $4.1 \pm 0.009^{\mathrm{Ab}}$ & $4.09 \pm 0.003^{\mathrm{Ab}}$ & $4.48 \pm 0.015^{\mathrm{Ab}}$ & $4.53 \pm 0.002^{\mathrm{Ab}}$ & $4.56 \pm 0.0023 \mathrm{Ab}$ \\
\hline \multirow{4}{*}{$\begin{array}{l}\text { Lipolysis } \\
\text { (meq/100 Oil) }\end{array}$} & P6 & $0.60 \pm 0.012 \mathrm{Aa}$ & $0.51 \pm 0.016^{\mathrm{Aa}}$ & $0.77 \pm 0.041 \mathrm{Aa}$ & $1.39 \pm 0.002^{\mathrm{Ab}}$ & $1.37 \pm 0.003 \mathrm{Ab}$ & $1.84 \pm 0.006^{\mathrm{Ac}}$ & $1.75 \pm 0.027 \mathrm{ABc}$ \\
\hline & $\mathrm{P} 12$ & $0.94 \pm 0.006^{\mathrm{Ab}}$ & $0.55 \pm 0.014 \mathrm{Aa}$ & $0.78 \pm 0.023^{\mathrm{Ac}}$ & $1.56 \pm 0.051 \mathrm{Ad}$ & $1.56 \pm 0.051 \mathrm{Ad}$ & $1.81 \pm 0.044 \mathrm{Ae}$ & $1.97 \pm 0.02 \mathrm{Ae}$ \\
\hline & R6 & $0.90 \pm 0.009 \mathrm{Aa}$ & $0.95 \pm 0.011 \mathrm{BCa}$ & $1.41 \pm 0.012^{\mathrm{Bb}}$ & $2.06 \pm 0.019 \mathrm{Bc}$ & $2.06 \pm 0.019 \mathrm{Bc}$ & $2.27 \pm 0.016^{\mathrm{Bbc}}$ & $2.39 \pm 0.012^{B c}$ \\
\hline & $\mathrm{R} 12$ & $0.90 \pm 0.009 \mathrm{Aa}$ & $1.12 \pm 0.006 \mathrm{Ca}$ & $2.14 \pm 0.007 \mathrm{Cb}$ & $2.41 \pm 0.008^{\mathrm{Bc}}$ & $2.41 \pm 0.008^{\mathrm{Bc}}$ & $2.76 \pm 0.002 \mathrm{Bcd}$ & $2.90 \pm 0.017 \mathrm{Cd}$ \\
\hline
\end{tabular}

P6: cheese produced from pasteurized milk and ripened at $6{ }^{\circ} \mathrm{C}$; P12: cheese produced from pasteurized milk and ripened at $12{ }^{\circ} \mathrm{C}$; R6: cheese produced from raw milk and ripened at $6{ }^{\circ} \mathrm{C} ;$ R12 cheese produced from raw milk and ripened at $12{ }^{\circ} \mathrm{C}$. ${ }^{\mathrm{A}-\mathrm{C}}$ Mean values in each column and from each parameter with different number differ significantly $(p<0.05)$. ${ }^{\text {a-e }}$ Mean values in each row different letters differ significantly $(p<0.05)$. 


\subsection{Lipolysis Changes during Ripening}

The lipolysis degree was affected $(p<0.05)$ by the pasteurization and ripening time and temperature (Table 2). The results showed that the amount of lipolysis increased during the ripening process of cheeses. The lipolysis degree was also higher in the cheeses produced from raw milk than the cheeses produced from pasteurized milk. The results of this study are parallel with Sert et al. [21], who evaluated lipolysis changes during ripening Tulum cheese which made from raw and pasteurized goat's milk. These authors showed that free fatty acids increase continuously during ripening, and they also observed that the rate of this increase was higher in cheeses produced from raw milk in compared to cheeses produced from pasteurized milk. Atasoy and Türkoğlu [27] and Katsiari et al. [39] also reported similar lipolysis changes in Urfa and Galotyri-type cheeses, respectively.

At the 90th day of ripening, R12 samples displayed the highest amount of lipolysis, and the P6 samples displayed the lowest amount of lipolysis. High microbial population of raw milk, as well as the deactivation of lipoprotein lipase enzyme (LPL) during pasteurization, may be the main reason for that [31]. The cheeses ripened at higher temperatures (P12 and R12) had more lipolysis than the cheeses ripened at lower temperatures (P6 and R6); the reason for that can be that the high temperature of ripening the cheese increased the activity of microorganisms and, consequently, the lipase activity, which is consistent with the results reported by Sihufe et al. [40].

\subsection{Change in the Percentage of Soluble Nitrogen in $p H=4.6$ to Total Nitrogen (\% SN/TN)}

Statistical results showed that the pasteurization and ripening time have a significant effect $(p<0.05)$ on $\% \mathrm{SN} / \mathrm{TN}$ values (Table 3$) . \% \mathrm{SN} / \mathrm{TN}$ in the cheese samples showed that its amount increased during ripening process, and the highest amount was observed in the R12 cheeses on day 90.

By studying the Pot cheeses, Khosrowshahi et al. [41] stated that \%SN/TN values in cheeses produced from raw milk was higher than cheeses produced from pasteurized milk. The results of experiments conducted by Aly and Gala [42] also observed the same trend according \%SN/TN values, which is possibly due to the effect of pasteurization on components of SN and presence of microbial flora and natural enzymes in the raw milk and non-starter lactic microorganisms [43]. Between the cheeses ripened at the temperatures of $6{ }^{\circ} \mathrm{C}$ and $12{ }^{\circ} \mathrm{C}$, the cheeses ripened at higher temperatures (P12 and R12) had higher \%SN/TN, probably due to the fact that the high temperature of ripening increases the proteolytic activity of rennet, plasmin, and bacteria and, thus, increases \%SN/TN [44]. 
Table 3. Classical nitrogen fractions of Motal cheese during the 90-day ripening process.

\begin{tabular}{|c|c|c|c|c|c|c|c|c|}
\hline & & \multicolumn{7}{|c|}{ Ripening Time (Day) } \\
\hline & & 1 & 15 & 30 & 45 & 60 & 75 & 90 \\
\hline \multirow{4}{*}{$\mathrm{SN} / \mathrm{TN}(\%)$} & P6 & $18.82 \pm 0.121 \mathrm{Aa}$ & $21.47 \pm 0.084^{\mathrm{Ab}}$ & $24.91 \pm 0.044^{\mathrm{Ab}}$ & $26.08 \pm 0.091 \mathrm{Ab}$ & $27.41 \pm 0.11 \mathrm{Ac}$ & $28.93 \pm 0.098$ Ac & $30.21 \pm 0.045^{\mathrm{Ac}}$ \\
\hline & $\mathrm{P} 12$ & $18.82 \pm 0.121 \mathrm{Aa}$ & $26.34 \pm 0.117^{\mathrm{Bb}}$ & $27.58 \pm 0.063^{\mathrm{Bb}}$ & $27.18 \pm 0.094 \mathrm{ABbc}$ & $29.81 \pm 0.058 \mathrm{ABc}$ & $30.81 \pm 0.089$ Ac & $30.72 \pm 0.118 \mathrm{Ac}$ \\
\hline & R6 & $24.88 \pm 0.083 \mathrm{Ba}$ & $28.54 \pm 0.092^{\mathrm{BCb}}$ & $29.88 \pm 0.073^{\mathrm{BCb}}$ & $30.57 \pm 0.102^{\mathrm{Bb}}$ & $31.27 \pm 0.041^{\mathrm{Bb}}$ & $33.67 \pm 0.099 \mathrm{Bc}$ & $34.88 \pm 0.058^{\mathrm{Bd}}$ \\
\hline & R12 & $24.88 \pm 0.086^{\mathrm{Ba}}$ & $30.92 \pm 0.083 \mathrm{Cb}$ & $32.76 \pm 0.099 \mathrm{Cbc}$ & $35.14 \pm 0.106^{\mathrm{Cbc}}$ & $37.25 \pm 0.115 \mathrm{Cbc}$ & $40.77 \pm 0.112^{\mathrm{Cc}}$ & $42.60 \pm 0.092^{C c}$ \\
\hline \multirow{4}{*}{ NPN/TN (\%) } & P6 & $1.20 \pm 0.092 \mathrm{Aa}$ & $1.9 \pm 0.094 \mathrm{Aa}$ & $2.84 \pm 0.103^{\mathrm{Ab}}$ & $4.34 \pm 0.132 \mathrm{Ac}$ & $5.58 \pm 0.098 \mathrm{Ac}$ & $7.88 \pm 0.074 \mathrm{Ad}$ & $9.03 \pm 0.117 \mathrm{Ad}$ \\
\hline & $\mathrm{P} 12$ & $1.20 \pm 0.092 \mathrm{Aa}$ & $2.25 \pm 0.084 \mathrm{ABb}$ & $3.79 \pm 0.122 \mathrm{ABc}$ & $4.2 \pm 0.175 \mathrm{Ac}$ & $6.54 \pm 0.161 \mathrm{ABd}$ & $8.23 \pm 0.078 \mathrm{Ae}$ & $8.92 \pm 0.109 \mathrm{Ae}$ \\
\hline & R6 & $3.1 \pm 0.089 \mathrm{Ba}$ & $3.7 \pm 0.091 \mathrm{BCb}$ & $4.21 \pm 0.112$ ВСс & $6.83 \pm 0.063 \mathrm{Bd}$ & $8.2 \pm 0.075 \mathrm{Bd}$ & $11.78 \pm 0.076^{\mathrm{BCe}}$ & $13.62 \pm 0.112 \mathrm{Be}$ \\
\hline & R12 & $3.1 \pm 0.089 \mathrm{Ba}$ & $4.8 \pm 0.98 \mathrm{Cb}$ & $5.51 \pm 0.117 \mathrm{Cb}$ & $8.53 \pm 0.96^{C c}$ & $10.16 \pm 0.118^{\mathrm{Cd}}$ & $12.62 \pm 0.094 \mathrm{Cd}$ & $14.74 \pm 0.087^{\mathrm{Be}}$ \\
\hline
\end{tabular}

P6: cheese produced from pasteurized milk and ripened at $6{ }^{\circ} \mathrm{C}$; P12: cheese produced from pasteurized milk and ripened at $12{ }^{\circ} \mathrm{C}$; R6: cheese produced from raw milk and ripened at $6{ }^{\circ} \mathrm{C}$;

$\mathrm{R} 12$ cheese produced from raw milk and ripened at $12^{\circ} \mathrm{C}$. ${ }^{\mathrm{A}-\mathrm{C}}$ Mean values in each column and from each parameter with different number differ significantly $(p<0.05)$. ${ }^{\mathrm{a}-\mathrm{e}}$ Mean values in each row different letters differ significantly $(p<0.05)$. 


\subsection{Studying the Degree of Casein Hydrolysis}

Decomposition in $\alpha_{\mathrm{s} 1}$ and $\beta$-casein and production of secondary products obtained from that in cheeses made from raw milk was more intense than cheeses made from pasteurized milk. According to Figure 1, rate of $\beta$-casein decomposition in R12 Motal cheeses was higher than other cheeses on day 90. The results of this study are in agreement with data reported by Pisanu et al. [45], who evaluated cheeses prepared with raw and pasteurized ovine milk on peptide profile. These authors showed that cheese made from raw milk had higher decomposition in $\alpha_{\mathrm{s} 1}$ and $\beta$-casein than cheeses made from pasteurized milk. Since the soluble nitrogen and protein nitrogen are the primary proteolysis index, applying the heat treatment has a significant effect on both primary and secondary proteolysis. At day 90, the amount of $\alpha_{\mathrm{s} 1}$-casein hydrolysis in the cheeses produced from raw milk (R6 and R12) was more than cheeses produced from pasteurized milk (P6 and P12). In addition, the $\beta$-casein bands slowly decreased during ripening, but its decrease was lower than $\alpha_{\mathrm{s} 1}$-casein, which demonstrated that $\beta$-casein is more resistant to proteolysis and its hydrolysis than $\alpha_{\mathrm{s} 1}$-casein. $\beta$-casein hydrolysis is affected by plasmin activity [46]. The difference between the amount of soluble nitrogen and casein decomposition between the cheese prepared from raw milk and pasteurized milk can also be due to the activity of non-starter peptidases in the raw milk. Furthermore, the presence of denatured whey proteins in pasteurized milk can affect the accessibility of proteases to casein [47]. Since the low storage temperature of cheese during the ripening prevent the activity Chymosin [46], we can conclude that, in the cheeses ripened at low temperature, the $\alpha_{\mathrm{s} 1}$-casein decomposition is lower than the cheeses ripened at high temperature.
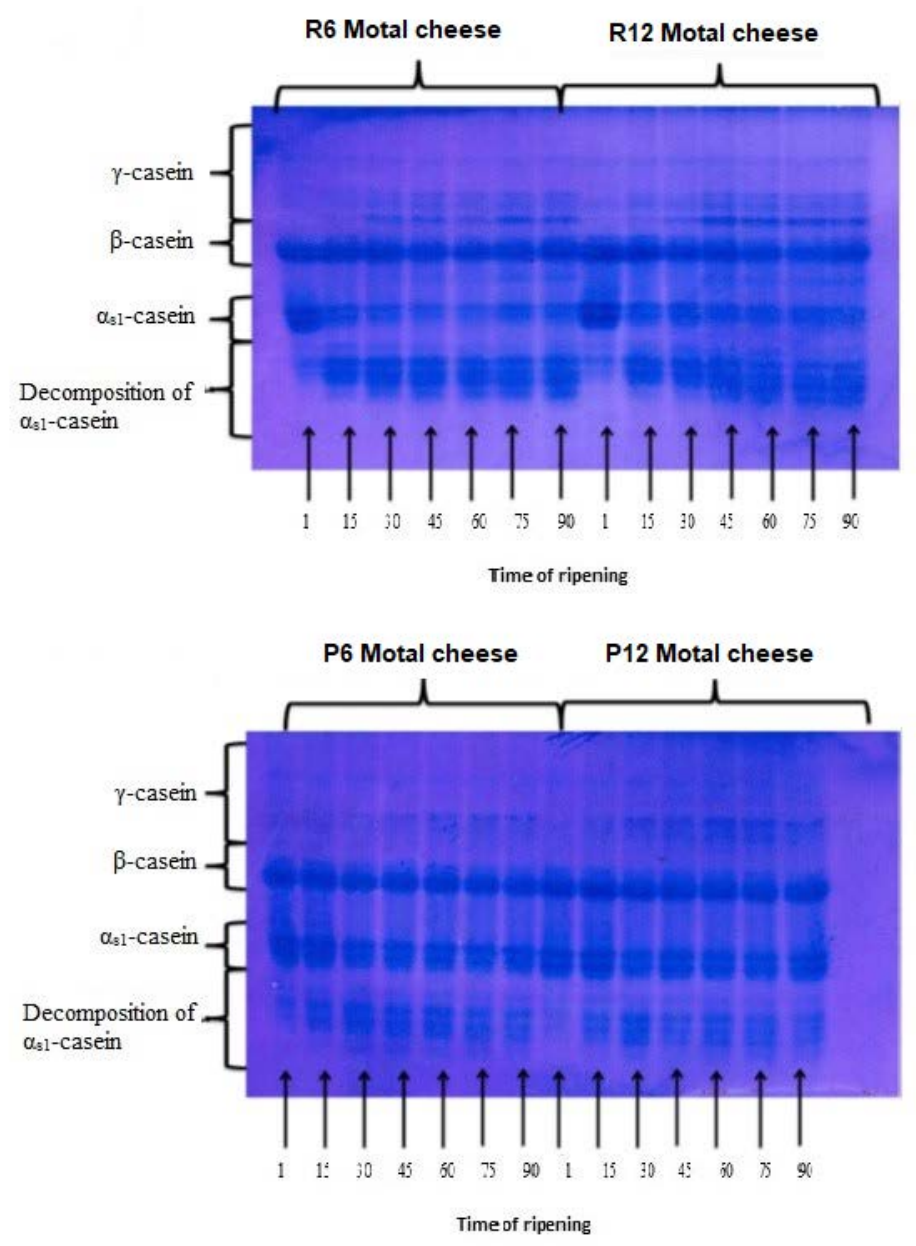

Figure 1. Electrophoretogram of insoluble phase of cheese produced from raw and pasteurized milk during ripening process. 
The degree of decomposition of $\alpha_{\mathrm{s} 1}$-casein and $\beta$-casein in the cheese samples during ripening period was consistent with the results obtained from the soluble nitrogen and non-casein nitrogen as follows: cheeses produced from raw milk at $12{ }^{\circ} \mathrm{C}(\mathrm{R} 12)>$ cheeses produced from raw milk at $6{ }^{\circ} \mathrm{C}$ (R6) $>$ cheeses produced from pasteurized milk at $12{ }^{\circ} \mathrm{C}(\mathrm{P} 12)>$ cheeses produced from pasteurized milk at $6{ }^{\circ} \mathrm{C}(\mathrm{P} 6)$.

\subsection{Sensory Evaluation during Ripening}

The results of evaluating the sensory characteristics of cheese at the end of ripening period are shown in the Figure 2. Results showed that the treatments had a significant effect on sensory characteristics. Except for yeasty-musty flavor, the other descriptors were significantly affected by the pasteurization and ripening temperature.

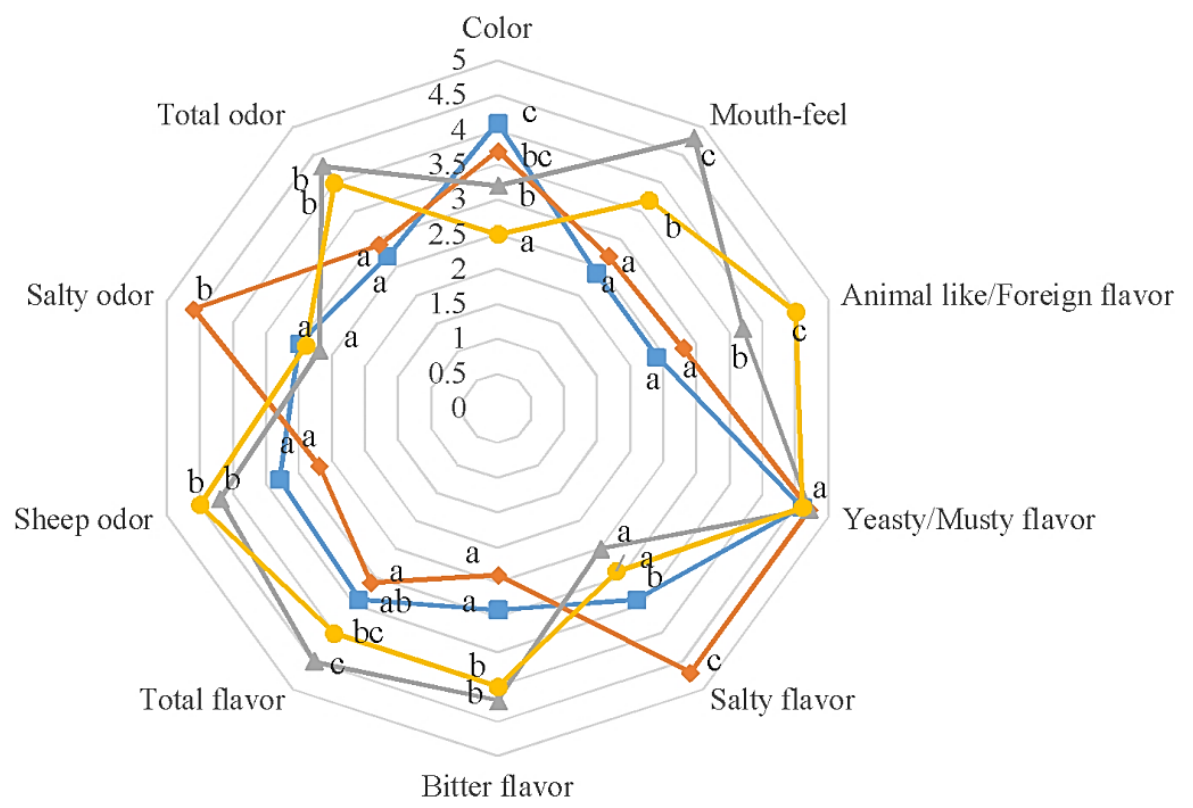

- P6 Motal cheese



$\longrightarrow$ R6 Motal cheese

$\longrightarrow$ R12 Motal cheese

Figure 2. Sensory characteristics of cheese at the end of ripening period. ${ }^{a, b}, \mathrm{c}$ Data differ significantly $(p<0.05)$.

The cheeses elaborated with raw milk showed the highest scores regarding mouth-feel, animal-like flavor, salty flavor, and odor and total odor, while cheeses produced from pasteurized milk showed the highest values of color, sheep odor, and bitter flavor.

In addition, the panelists gave the highest scores of total cheese flavor for R6 Motal cheese, perhaps due to higher total flavor, total odor, and better organoleptic characteristics (due to lack of pasteurization) of the cheese milk. Our outcome agrees with data reported by Torracca et al. [48], who evaluated effects of pasteurization on sensory properties of pecorino cheese. These authors showed that the samples elaborated with raw milk had high sensory properties (including flavor and odor) compared to samples manufactured with pasteurized milk. Furthermore, Pappa et al. [49] and Sert et al. [21] also reported similar results in Kashkaval and Tulum cheese, respectively, which were made from raw and pasteurized milk.

\section{Conclusions}

In this study, pasteurization process, ripening time, and ripening temperature influenced chemical, physicochemical, and sensory properties of traditional Motal cheeses. As expected, as the ripening progressed, the moisture loss resulted in a higher amount of the other parameters (dry matter, fat, 
protein, salt, and intensity of lipolysis), while the $\mathrm{pH}$ decreased during the first 60 days and then increased. The acidity showed a contrary tendency to $\mathrm{pH}$. The pasteurization process of the milk resulted in higher dry matter values in the cheese and, thus, higher amount of the other parameters. Similarly, the ripening process at higher temperature increased the dry matter, fat, protein, and salt. On the other hand, the pasteurization process and the low ripening temperatures inhibited the enzyme and/or bacterial activity, thus reducing lipolysis and proteolysis phenomenon. Obviously, both parameters increase with the increased ripening process. Finally, the sensory analysis showed that all treatments influenced the organoleptic characteristics of the cheeses. The highest scores of total flavor was observed in the cheeses ripened at $6{ }^{\circ} \mathrm{C}$ and elaborated with raw milk (R6). However, sensory quality should be further investigated, including consumer acceptability and preference studies, in future research. As a general conclusion, the pasteurization process, together with the addition of starters and a low-temperature ripening, allows us to have a homogeneous product and ensure the microbiological stability of the product, as well as showing several benefits (higher dry matter, protein, and fat content than raw cheeses) and controlling and limiting the proteolysis and lipolysis processes.

Author Contributions: Conceptualization, S.A.D. and K.A.; formal analysis, A.R.; writing-original draft preparation, A.R., J.H. and M.Y.; writing—review and editing, P.P., R.D. and J.M.L. All authors have read and agreed to the published version of the manuscript.

Funding: This research received no external funding.

Acknowledgments: Thanks to GAIN (Axencia Galega de Innovación) for supporting this research (grant number IN607A2019/01).

Conflicts of Interest: The authors declare no conflict of interest.

\section{References}

1. Kamber, U. The traditional cheeses of Turkey: Eastern Anatolia Region. Food Rev. Int. 2008, 24, 148-174. [CrossRef]

2. Oluk, A.C.; Guven, M.; Hayaloglu, A.A. Influence of exopolysaccharide-producing cultures on the volatile profile and sensory quality of low-fat Tulum cheese during ripening. Int. J. Dairy Technol. 2014, 67, 265-276. [CrossRef]

3. Alirezalu, K.; Inácio, R.S.; Hesari, J.; Remize, F.; Nemati, Z.; Saraiva, J.A.; Barba, F..; Sant'Ana, A.S.; Lorenzo, J.M. Nutritional, chemical, syneresis, sensory properties, and shelf life of Iranian traditional yoghurts during storage. LWT 2019, 114, 108417. [CrossRef]

4. Kousta, M.; Mataragas, M.; Skandamis, P.; Drosinos, E.H. Prevalence and sources of cheese contamination with pathogens at farm and processing levels. Food Control. 2010, 21, 805-815. [CrossRef]

5. Verraes, C.; Vlaemynck, G.; Van Weyenberg, S.; De Zutter, L.; Daube, G.; Sindic, M.; Uyttendaele, M.; Herman, L. A review of the microbiological hazards of dairy products made from raw milk. Int. Dairy J. 2015, 50, 32-44. [CrossRef]

6. Giaccone, D.; Revello-Chion, A.; Galassi, L.; Bianchi, P.; Battelli, G.; Coppa, M.; Tabacco, E.; Borreani, G. Effect of milk thermisation and farming system on cheese sensory profile and fatty acid composition. Int. Dairy J. 2016, 59, 10-19. [CrossRef]

7. Benfeldt, C.; Sorensen, J. Heat treatment of cheese milk: Effect on proteolysis during cheese ripening. Int. Dairy J. 2001, 11, 567-574. [CrossRef]

8. Buffa, M.; Guamis, B.; Saldo, J.; Trujillo, A.J. Changes in organic acids during ripening of cheeses made from raw, pasteurized or high-pressure-treated goats' milk. LWT-Food Sci. Technol. 2004, 37, 247-253. [CrossRef]

9. Çakir, Y.; Çakmakçi, S. Some microbiological, physicochemical and ripening properties of Erzincan Tulum cheese produced with added black cumin (Nigella sativa L.). J. Food Sci. Technol. 2018, 55, 1435-1443. [CrossRef]

10. McSweeney, P.L.H.; Sousa, M.J. Biochemical pathways for the production of flavour compounds in cheeses during ripening: A review. Lait 2000, 80, 293-324. [CrossRef] 
11. Buffa, M.N.; Trujillo, A.J.; Pavia, M.; Guamis, B. Changes in textural, microstructural, and colour characteristics during ripening of cheeses made from raw, pasteurized or high-pressure-treated goats' milk. Int. Dairy J. 2001, 11, 927-934. [CrossRef]

12. Martins, A.A.; Santos-Junior, V.A.; Filho, E.R.T.; Silva, H.L.A.; Ferreira, M.V.S.; Graça, J.S.; Esmerino, E.A.; Lollo, P.C.B.; Freitas, M.Q.; Sant'Ana, A.S.; et al. Probiotic Prato cheese consumption attenuates development of renal calculi in animal model of urolithiasis. J. Funct. Foods 2018, 49, 378-383. [CrossRef]

13. Marshall, T.M. Standard Methods For the Examination of Dairy Products, 16th ed.; American Public Health Association: Washington, DC, USA, 1992.

14. Nuñez, M.; García-Aser, C.; Rodríguez-Martin, M.A.; Medina, M.; Gaya, P. The effect of ripening and cooking temperatures on proteolysis and lipolysis in Manchego cheese. Food Chem. 1986, 21, 115-123. [CrossRef]

15. Sousa, M.J.; McSweeney, P.L.H. Studies on the ripening of Cooleeney, an Irish farmhouse Camembert-type cheese. Ir. J. Agric. Food Res. 2001, 40, 83-95.

16. Andrews, A.T. Proteinases in normal bovine milk and their action on caseins. J. Dairy Res. 1983, 50, 45-55. [CrossRef]

17. Kaminarides, S.E.; Koukiassa, P. Detection of bovine milk in ovine yoghurt by electrophoresis of para-k-casein. Food Chem. 2002, 78, 53-55. [CrossRef]

18. Shalabi, S.I.; Fox, P.F. Electrophoretic Analysis of Cheese: Comparison of Methods. Ir. J. Food Sci. Technol. 1987, 11, 135-151.

19. Bodyfelt, F.W.; Tobias, J.; Trout, G.M. The sensory evaluation of dairy products. In The Sensory Evaluation of Dairy Products; Clark, S., Costello, M., Drake, M.A., Bodyfelt, F., Eds.; Van Nostrand Reinhold: New York, NY, USA, 1988.

20. Ebadi Nezhad, S.J.; Edalatian Dovom, M.R.; Habibi Najafi, M.B.; Yavarmanesh, M.; Mayo, B. Technological characteristics of Lactobacillus spp. isolated from Iranian raw milk Motal cheese. LWT 2020, 133, 110070. [CrossRef]

21. Sert, D.; Akin, N.; Aktumsek, A. Lipolysis in Tulum cheese produced from raw and pasteurized goats' milk during ripening. Small Rumin. Res. 2014, 121, 351-360. [CrossRef]

22. Bayar, N.; Ozrenk, E. The effect of quality properties on Tulum cheese using different package materials. Afr. J. Biotecnol. 2011, 10, 1393-1399.

23. Psoni, L.; Tzanetakis, N.; Litopoulou-Tzanetaki, E. Characteristics of Batzos cheese made from raw, pasteurized and/or pasteurized standardized goat milk and a native culture. Food Control. 2006, 17, 533-539. [CrossRef]

24. Marino, V.M.; Schadt, I. Stability of a-tocopherol, g-tocopherol and b-carotene during ripening of pasta-filata cheese made from raw and pasteurised milk with different vitamin contents. J. Dairy Sci. 2016, 56, 29-32. [CrossRef]

25. Gaya, P.; Medina, M.; Rodriguez-Marin, M.A.; Nuñez, M. Accelerated Ripening of Ewes' Milk Manchego Cheese: The Effect of Elevated Ripening Temperatures. J. Dairy Sci. 1990, 73, 26-32. [CrossRef]

26. Fox, P.F.; Guinee, T.P.; Cogan, T.M.; McSweeney, P.L.H. Fundamentals of Cheese Science, 2nd ed.; Springer: New York, NY, USA, 2016; ISBN 9781489976819.

27. Atasoy, A.F.; Türkoğlu, H. Changes of composition and free fatty acid contents of Urfa cheeses (a white-brined Turkish cheese) during ripening: Effects of heat treatments and starter cultures. Food Chem. 2008, 110, 598-604. [CrossRef]

28. Folkertsma, B.; Fox, P.F.; Mcsweeney, P.L.H. Acceleration ripening of cheddar cheese at elevated temperatures. Int. Dairy Sci. 1996, 6, 1117-1134. [CrossRef]

29. Kujawski, M.; Cichosz, G.; Podhajna, E.; Sanko, B. Effect of ripening temperature on proteolysis and organoleptic properties of Edam-type cheese. Food Sci. Technol. 2003, 6, 207-219.

30. Pastorino, A.J.; Hansen, C.L.; McMahon, D.J. Effect of salt on structure-function relationships of cheese. J. Dairy Sci. 2003, 86, 60-69. [CrossRef]

31. Hayaloglu, A.A.; Deegan, K.C.; Mcsweeney, P.L.H. Effect of milk pasteurization and curd scalding temperature on proteolysis in Malatya, a Halloumi-type cheese. Dairy Sci. Technol. 2010, 2010, 99-109. [CrossRef]

32. Abdalla, M.O.M.; Ibrahim, N.N.M. Chemical and microbiological evaluation of Mozzarella cheese during storage. Aust. J. Basic Appl. Sci. 2010, 4, 532-536.

33. Abo El-Nor, S.A.H.; Shahein, N.M.; Rabou, N.S.A. Effect of protein feeding system on the quality of milk and its resultant Domiati Cheese. J. Am. Sci. 2011, 7, 282-290. 
34. Goncu, A.; Alpkent, Z. Sensory and chemical properties of white pickled cheese produced using kefir, yoghurt or a commercial cheese culture as a starter. Int. Dairy J. 2005, 15, 771-776. [CrossRef]

35. Bakirci, H.; Kavaz, A.; Macit, E. Effect of different brine concentrations and ripening period on some quality properties of Turkish white pickled cheese. Afr. J. Biotechnol. 2011, 10, 11925-11931.

36. Corredig, M.; Dalgleish, D.G. Effect of different heat treatments on the strong binding interactions between whey proteins and milk fat globules in whole milk. J. Dairy Res. 1996, 63, 441-449. [CrossRef]

37. Rehman, S.U.; McSweeney, P.L.H.; Banks, J.M.; Brechany, E.Y.; Muir, D.D.; Fox, P.F. Ripening of Cheddar cheese made from blends of raw and pasteurised milk. Int. Dairy J. 2000, 10, 33-44. [CrossRef]

38. Ismail, M.M.; Ammar, E.-T.M.A.; El-Shazly, A.A.; Eid, M.Z. Impact of cold storage and blending different lactations of cow's milk on the quality of Domiati cheese. Afr. J. Food Sci. 2010, 4, 503-513.

39. Katsiari, M.C.; Kondyli, E.; Voutsinas, L.P. The quality of Galotyri-type cheese made with different starter cultures. Food Control 2009, 20, 113-118. [CrossRef]

40. Sihufe, G.A.; Zorrilla, S.E.; Mercanti, D.J.; Perotti, M.C.; Zalazar, C.A.; Rubiolo, A.C. The influence of ripening temperature and sampling site on the lipolysis in Reggianito Argentino cheese. Food Res. Int. 2007, 40, 1220-1226. [CrossRef]

41. Khosrowshahi, A.; Madadlou, A.; Mousavi, M.E.Z.; Emam-Djomeh, Z. Monitoring the chemical and textural changes during ripening of Iranian white cheese made with different concentrations of starter. J. Dairy Sci. 2006, 89, 3318-3325. [CrossRef]

42. Aly, A.S.; Gala, E.A. Effect of milk pretreatment on the keeping quality of Domiati cheese. Pak. J. Nutr. 2002, 1, 132-136.

43. Awad, S. Texture and flavour development in Ras cheese made from raw and pasteurised milk. Food Chem. 2006, 97, 394-400. [CrossRef]

44. Klantschitsch, T.; Bachmann, H.-P.; Puhan, Z. Influence of milk treatment and ripening conditions on quality of Raclette cheese. Lait 2000, 80, 51-67. [CrossRef]

45. Pisanu, S.; Pagnozzi, D.; Pes, M.; Pirisi, A.; Roggio, T.; Uzzau, S.; Addis, M.F. Differences in the peptide profile of raw and pasteurised ovine milk cheese and implications for its bioactive potential. Int. Dairy J. 2015, 42, 26-33. [CrossRef]

46. Madsen, J.S.; Ardö, Y. Exploratory study of proteolysis, rheology and sensory properties of Danbo cheese with different fat contents. Int. Dairy J. 2001, 11, 423-431. [CrossRef]

47. Lau, K.Y.; Barbano, D.M.; Rasmussen, R.R. Influence of pasteurization of milk on protein breakdown in Cheddar cheese during aging. J. Dairy Sci. 1991, 74, 727-740. [CrossRef]

48. Torracca, B.; Pedonese, F.; López, M.B.; Turchi, B.; Fratini, F.; Nuvoloni, R. Effect of milk pasteurisation and of ripening in a cave on biogenic amine content and sensory properties of a pecorino cheese. Int. Dairy J. 2016, 61, 189-195. [CrossRef]

49. Pappa, E.C.; Kondyli, E.; Samelis, J. Microbiological and biochemical characteristics of Kashkaval cheese produced using pasteurised or raw milk. Int. Dairy J. 2019, 89, 60-67. [CrossRef]

(C) 2020 by the authors. Licensee MDPI, Basel, Switzerland. This article is an open access article distributed under the terms and conditions of the Creative Commons Attribution (CC BY) license (http://creativecommons.org/licenses/by/4.0/). 